\title{
Natural Gas Demand Estimation for India: Error Correction Modelling
}

\author{
Atul Rawat, Sumeet Gupta, T. Joji Rao, Sushil Kumar Rai
}

\begin{abstract}
Share of fossil fuel in India's primary energy mix is around $92 \%$ with natural gas contributing $6 \%$ in it. The power, fertilizer and city gas distribution (CGD) sector are the major gas-consuming sector in India. Despite the government efforts to increase the share of natural gas in the primary energy mix, the country still has low per capita gas consumption. In order to enhance natural gas consumption in the country, the Indian government has set up a target to increase natural gas share in the energy mix to $15 \%$ by 2022. Therefore, the issue of estimation of the natural gas demand is addressed in the present paper to understand the dynamics of the natural gas market. The error correction model (ECM) is applied at a national and sectoral level to examine the domestic gas demand in India. The study reveals the following findings: (a) At the national and sectoral level, the last year gas consumption is an only statistically significant factor; (b) Price, population and income are not statistically significant at national and sectoral level and (c) Demand for natural gas is price inelastic at the national level.
\end{abstract}

Index Terms: Demand Estimation, Error Correction, India, Natural Gas

\section{INTRODUCTION}

India is growing faster than any other major economy except for China. The country is expected to become the second largest economy in the world, behind only China [1]. Energy availability is among one of the key parameters for ensuring sustainable economic growth. High economic growth would lead to an increase in the energy demand of the country. India is home to around $18 \%$ of the global population but it consumes only $5.5 \%$ of the world's primary energy and its per capita consumption is only one-third of the global average [1].

India is the third largest energy consumer in the world after China and the US, consuming 723.9 MMTOE in 2017. The country's primary energy mix is dominated by coal and crude oil, which have a combined contribution of around $86 \%$. Natural gas share in India's primary energy consumption rose steadily until 2011 when it reached $10 \%$. However, its share fell to around $6 \%$ in 2017 [1]. The country's per capita natural gas consumption is among the lowest in the world, with 40 cubic meter per capita compared to the global average of 487 cubic meter per capita. This clearly indicates that there is a huge opportunity for increasing the share of natural gas in the energy mix [1].

Natural gas consumption reached its peak in 2010 with a contribution of $10.6 \%$ in the total energy mix. However, its consumption started declining since then because of falling domestic gas production and high price imported LNG until 2015. The country natural gas production has declined to 29 BCM in 2017 from 48 BCM in 2010 at a CAGR of $6.9 \%$. On the other hand, natural gas consumption declined to $54 \mathrm{BCM}$ in 2017 from 59 BCM in 2010 at a CAGR of $-0.8 \%$. However, after witnessing five years of continuous decline, gas consumption surged to $50 \mathrm{BCM}$ on the back of increased sales to CGD sector. The demand-supply gap is widening with each passing year, which is met by imported Liquefied Natural Gas (LNG). India's LNG import has increased by $37 \%$ over 2015 to $26 \mathrm{BCM}$ in 2017, making India the fourth largest LNG importer [1].

The current Indian government thrust is to make India a gas-based economy and boost the share of natural gas in the energy mix to $15 \%$ by 2022 [1]. The intent is to renovate energy mix on account of increased substitution of oil and coal by natural gas. The continued focus on increasing the share of natural gas in energy mix would lead to a rise in demand for this commodity in the supply constraint country. Hence, the imperative of natural gas demand estimation is very high to ensure uninterrupted supply for the growing Indian economy.

It is crucial for any country to develop energy demand forecasting model to plan future capacity development, making investment decisions, coordinate import activities and plan international trade. In the Indian context, the most of energy demand projections were made in an old-fashioned way with trend extrapolations. This paper aims to develop a model for India using the dynamic econometric techniques for forecasting natural gas demand. Although the research is primarily focused on India, this used natural gas demand model can be used for the other developing countries.

This paper is organized as follows. Section 2 discusses the natural gas demand model with its outcomes. Section 3 discusses the finding and conclusion.
Revised Manuscript Received on July 22, 2019.

Atul Rawat, Energy Management, University of Petroleum \& Energy Studies, Dehradun, India.

Sumeet Gupta, General Management, University of Petroleum \& Energy Studies, Dehradun, India.

T. Joji Rao, General Management, University of Petroleum \& Energy Studies, Dehradun, India

Sushil Kumar Rai, Economics \& IB, University of Petroleum \& Energy Studies, Dehradun, India. 


\section{Natural Gas Demand Model}

\section{A. Energy Demand Models}

Energy plays a crucial role in ensuring the sustainable development of any developing nation, comprising economic, social or environmental. Indian energy consumption has increased exponentially because of sustainable economic growth in the last decade. Managing energy demand is a must for proper resource allocation, therefore making energy demand modeling and forecasting an extensively researched area among the academicians. During the past decade, researchers have developed several new models for energy demand forecasting to achieve varying objectives, proving modeling philosophies, developing new modeling methods.

Generally, energy-forecasting models depend on the prevailing economic, social and market conditions, e.g. Baines and Bodger used market-forecasting approach for energy demand analysis [1]. Often, these factors can be inter-related; requiring a large dataset for sophisticated modeling or shortage of data may lead to the development of a simple model.

There are many studies conducted to review the present energy demand models for forecasting energy demand in the developing economies [1] [1] [1]. [1]Identifies the key indicators commonly used for demand forecasting - growth rates, elasticities, specific consumption and energy intensity in developing economies. These methods require limited data and straightforward interpretations. The single equation approach based model often outperforms complex specification and yields result with minimal skill set. The frequently used models for forecasting energy demands are econometric, hybrid, trend, engineering economic, system dynamic, scenario development approaches, input-output, and artificial neural network models.

The econometric and trend models are also classified as a top-down model as they use the information at the aggregate level. A trend model enables researcher to discover a statistical relationship between energy demand and times using the past data. It is the frequently used method adopted for energy demand forecasting in the developing countries. Whereas, econometric models link energy consumption with the technology, economy, and the environment and are well grounded with the economic theory. Moreover, econometric models are more reliable for short and medium-term forecasting. Artificial neural network models have similarity too econometric models but lack the theoretical foundations of economics. In these models, the functional relationships amid energy demand and its drivers are determined using neural networks.

Engineering - economy model (or end-use) focuses on energy accounting using the detailed engineering depiction of the energy system. Such models rely on a disaggregated approach, focuses on economic, technological and social factors, and developed scenarios to forecast the long-term energy demand. These models are excellent in capturing structural variations and technological developments [1]. However, the end-use models are less useful in forecasting demand for developing countries on account of data availability. An input-output model symbolizes the interdependencies between different sectors of a national

economy or different regional economies. It's a data-intensive and thus less suitable for developing nations.

The other models include scenario approaches and hybrid models. The former models are least technical and rely on expert judgments on future performance. Generally, they are an integrated part of end-use models and require minimum data. Despite the dearth of theoretical underpinning, scenario models are used for long-term planning [1].The hybrid models reduce the methodological differences between the engineering and econometric models by combining the two traditions. These models have been used widely for energy demand forecasting in developing economies.

Among all the models discussed above for energy demand forecasting, econometric models with time-series information along with the related demand drivers are the most appropriate for the developing economies. The unavailability of the relevant data in the developing nations restricts the development of more sophisticated models. Despite many econometric models developed in the past for various energy carriers like petroleum products, solar, wind, electricity, primary energy or coal, there are very few studies conducted on natural gas demand estimation for India. In the past, many studies were conducted in developing nations primarily focused on residential natural gas demand. In most of the developing nations, natural gas role in the energy mix is small as it is used in specific sectors. However, there is some exception such as Turkey.[1] Estimates short and long-run price and income elasticities of sectoral natural gas demand in Turkey using ARIMA Model. Similarly, [1] uses system dynamics model to create a natural gas outlook. In addition, scenario analysis is used to verify the results.

\section{B. Natural Gas Demand Models in India}

India's energy demand is expanding with each passing owing to consistent economic growth. The country imports around $80 \%$ and $40 \%$ of crude oil and natural gas requirement, respectively. Despite the increasing use of natural gas in the Indian energy mix, the demand models used for gas demand forecasting in India are elementary. In 1981, driven by the findings of Working Group on Energy Policy, [1]forecasted energy demand was based on a reference and optimal level scenarios. The research concludes with the presentation of an Energy-Economic Modeling framework for evaluating energy policies and development plans within a macroeconomic planning framework. Rao and Parikh studied the demand for petroleum products in India using econometric models grounded on time series data to capture specific factors influencing product demand [1]. [1] conducted a study to look at different factors that affect the energy demand in India and developed the energy and environmental outlook. It was achieved by developing an integrated mathematical model including several factors such as GDP, population growth, urbanization, energy intensity, structural shifts, energy efficiency measures, fuel switching, appropriate energy pricing mechanism, and environmental policies. 
Sustainable Energy Planning (SEP) scenario was developed using this framework [1]. [1] developed econometric models for different petroleum products separately with the aim of capturing product-specific variables. The projections were done by using two scenarios of annual GDP of $6 \%$ and $8 \%$. [1] presented the forecasting models based on Artificial Neural Network for the consumption of energy resources in India. [1] applied three-time series models: Grey-Markov, Grey-Model with rolling mechanism and Singular spectrum analysis (SSA) to predict petroleum, coal, and electricity, and natural gas consumption respectively. The study concludes that the time series models can be a feasible alternative for energy demand forecasting.

\section{Proposed Demand Model}

There are not many models developed for natural gas demand estimation in India. Most of the natural gas models for India fail to recognize that natural gas demand depends on many external drivers such economy, population growth, income, commodity price, environmental factors, technological breakthrough, regulatory or policy changes, etc. Among these indicators, price and income have been the significant parameters. The positive relationship between GDP or income and energy has been documented in various studies [1][1][2][3][1]. Similarly, the negative influence of price has also been documented, especially in the transport sector [1][1][1][1] In case of India, [4] established a long-run equilibrium relationship among the quantity of crude oil import, income and price of the imported crude in India using autoregressive distributed lag (ARDL) bounds testing approach of cointegration. The study results show that there exists a unidirectional long-run causality running from economic growth to crude oil import. However, the inadequate information on the other demand drivers limits the majority of energy demand studies in developing economies to these two variables only [5]. We too have used these two variables in estimating the natural gas demand in India.

There are few variations possible for using gas demand and GDP variables. In our model, we have used total natural gas demand as a function of per capita GDP, price and population. We can also model collective natural gas demand pertaining to aggregate GDP. The other possible alternative is model per capita demand based on per capita GDP. We have focused on estimating the aggregate demand as it is the most significant variable for policymakers for planning requirements.

There are many functional options are possible for developing the demand model - linear, non-linear, semilog, etc for defining the mathematical connection between the demand variables. We have followed the log-linear Cobb-Douglas for demand modeling as it most used function. The parameter estimates of the explanatory variables are directly the elasticities of demand. These elasticities considered constant. Moreover, the log-linear models had better represent the non-linear nature of the variables [6].

According to the Cobb-Douglas form, the natural gas demand is:

Gas $=\mathrm{C}($ Price $) \alpha($ GDP $) \beta[$ (Population) $\gamma]$

Taking logarithm on both sides, and considering the error term
In Gast $=\mathrm{k}+\alpha$ InPricet $+\beta \operatorname{InGDPt}+\gamma[$ Populationt $]+\varepsilon \mathrm{t}$

Where: Gas is the natural gas demand at time $t$;

Price is the natural gas price at time $t$;

GDP is the real GDP at time $\mathrm{t}$;

[Population] is the population at time $t$, if it is included in the model;

$\alpha, \beta$ and $\gamma$ are the parameters to be estimated;

Our estimated demand model is an improvement over the previously used model. In our model, we have addressed the problem of non-stationarity, multicollinearity, heteroscedasticity and normal distribution of error terms. A non-stationary series leads to spurious and nonsense regression. We have applied the Augmented Dickey-Fuller Test and Phillips-Perron Test to check the stationarity of series. The problem of multicollinearity among the explanatory variables is responsible for the insignificant slope coefficients but a high overall R-square value. To overcome this problem, we used Variance-inflating factor (VIF) and Tolerance level (TOL). We used the Breusch-Pagan-Godfrey test to check the heteroscedasticity in our estimated model. The regression model assumes that the error term relating to any observation is not influenced by the error term of the many other observations. This issue is addressed by conducting the Breusch-Godfrey Serial Correlation LM Test. There is a high probability that gas demand does not react instantly to rise in GDP because of high capital investment requirement and long project gestation period. Therefore, we incorporated a lagged dependent variable among the explanatory variables to address the above-mentioned issue by developing a dynamic model as given below.

In Gast $=\mathrm{k}+\Sigma \mathrm{i} \mu \mathrm{iInGast}-\mathrm{i}+\alpha$ InPricet $+\beta$ InGDPt + $\gamma[$ InPopulationt $]+\varepsilon \mathrm{t}$

Where, $\mu \mathrm{i}$ are the parameters to be estimated; $i$ is the Lag length.

Error Correction Model (ECM): ECM has been applied to find out the process of adjustments of the estimated model towards the equilibrium. The ECM model is applied by using the Engel-Granger procedure in two steps. In the first step, ordinary least squares are used with the variables, which are non-stationary at levels but integrated of order I (1). The stationarity of the residuals of the estimated regression equation implies a cointegration among the variables in the long-run. In the second step, the error correction model is applied by using the residual from the estimated equation to explain the short-run behavior of the natural gas demand to its long-run value. The equation for the error correction model is In Gast $=\mathrm{k}+\Sigma \mathrm{i} \mu \mathrm{iInGast}-\mathrm{i}+\alpha$ InPricet $+\beta$ InGDPt + $\gamma[$ InPopulationt $]+\varepsilon t$

Where, $\varepsilon \mathrm{t}=$ In Gast $-\mathrm{k}+\sum \mathrm{i} \mu \mathrm{iInGast}-\mathrm{i}+\alpha$ InPricet + $\beta$ InGDPt $+\gamma[$ InPopulationt $]$

$\Delta$ In Gast $=\mathrm{k}+\Sigma \mathrm{i} \mu \mathrm{i} \Delta$ InGast-i $+\alpha \Delta \operatorname{InPricet}+\beta \Delta \operatorname{InGDPt}+$ $\gamma[\Delta$ InPopulationt $]+\psi \varepsilon \mathrm{t}-1+\mathrm{vt}$ 
Where ot is the error term; and the absolute value of coefficient $\psi$ will decide how quickly the equilibrium is reached.

$\varepsilon \mathrm{t}-1=$ In Gast-1 - $\mathrm{k}+\sum \mathrm{i} \mu \mathrm{iInGast- \textrm {i } - 1}+\alpha$ InPricet-1 + $\beta$ InGDPt- $1+\gamma[$ InPopulationt-1]

\section{DATA}

The model works on time series data. This data for all the variables were collected from the reliable sources. The annual gas price data was referred from Mahanagar Gas Limited. The natural gas prices in India were very complex until 2014. Because of the change in the Government in May 2014, the prevailing gas pricing policy was re-examined. In October 2014, the Cabinet Committee of Economic Affairs (CCEA) accepted the new domestic gas pricing policy. The committee recommended a new approach for gas price determination, built on the modification to the Rangarajan formula. The committee removed both the Japanese and Indian LNG import components in the original formula and included Alberta Gas Reference price and Russian actual price. The periodicity of price determination/notification shall be half yearly [1]. The new formula approved by CCEA is

$\mathrm{P}=\mathrm{VHH} * \mathrm{PHH}+\mathrm{VAC} * \mathrm{PAC}+\mathrm{VNBP} * \mathrm{PNBP}+\mathrm{VR} * \mathrm{PR} /$

$\mathrm{VHH}+\mathrm{VAC}+\mathrm{VNBP}+\mathrm{VR}$

Where,

(a) $\mathrm{VHH}=$ Total annual volume of natural gas consumed in the USA \& Mexico.

(b) $\mathrm{VAC}=$ Total annual volume of natural gas consumed in Canada.

(c) VNBP = Total annual volume of natural gas consumed in the EU and FSU, excluding Russia.

(d) VR = Total annual volume of natural gas consumed in Russia.

(e) PHH and PNBP are the annual averages of daily prices at Henry Hub (HH) and National Balancing Point (NBP) less the transportation and treatment charges.

(f) PAC and PR are the annual averages of monthly prices at Alberta Hub and Russia respectively less the transportation and treatment charges

Since gas pricing policy has changed multiple time in the past, we have used the weighted average selling price for the year is being used for this study. Population, GDP and per capita GDP data were used and collected from World Development Indicators of the World Bank [1]. Natural gas consumption data for the different sectors of the economy is available in Energy Statistics [1]. To calculate state demand for natural gas, we have taken gas consumption data from Energy Statistics [1] and state GDP and State population data from the Reserve Bank of India annual database [1].

\section{FINDINGS}

The two models are used for estimating the natural gas demand in India: first, where the explanatory variables contain total GDP (Model A) and second where it contains population and GDP per capita (Model B). Both the models have common variants such as natural gas prices and lagged consumption. To identify the best model, we focused on the model fit diagnostics such as adjusted R2, Akaike Information Criteria (AIC), VIF, TOL, Residuals Normality Test, Serial

Correlation LM test, and Heteroscedasticity test.

Time-series regression analysis is based on the assumption that the series under consideration must be stationary. The unit root test is applied to check the stationarity on the considered variables. The result of the test has been shown in Table 1: Results of Unit Root Test Table 1:

\begin{tabular}{|c|c|c|c|c|}
\hline \multirow[t]{2}{*}{ Variables } & \multicolumn{2}{|c|}{$\begin{array}{c}\text { Augmented } \\
\text { Dickey-Fuller Test }\end{array}$} & \multicolumn{2}{|c|}{ Phillips-Perron Test } \\
\hline & At Level & $\begin{array}{l}\text { First } \\
\text { Difference }\end{array}$ & At Level & $\begin{array}{l}\text { First } \\
\text { Difference }\end{array}$ \\
\hline LTGASON & $\begin{array}{l}-2.4741 \\
(0.1284)\end{array}$ & $\begin{array}{l}-4.7472 \\
(0.0004) *\end{array}$ & $\begin{array}{l}-2.4741 \\
(0.1284)\end{array}$ & $\begin{array}{l}-4.7354 \\
(0.0004) *\end{array}$ \\
\hline LPRICE & $\begin{array}{l}-2.2212 \\
(0.2018)\end{array}$ & $\begin{array}{l}-5.9822 \\
(0.0000) *\end{array}$ & $\begin{array}{l}-2.2401 \\
(0.1955)\end{array}$ & $\begin{array}{l}-5.9635 \\
(0.0000) *\end{array}$ \\
\hline LGDP & $\begin{array}{l}-0.1485 \\
(0.9374)\end{array}$ & $\begin{array}{l}-6.1236 \\
(0.0000) *\end{array}$ & $\begin{array}{l}-0.1884 \\
(0.9324)\end{array}$ & $\begin{array}{l}-6.1436 \\
(0.0000) *\end{array}$ \\
\hline LGDPP & $\begin{array}{l}0.1091 \\
(0.9630)\end{array}$ & $\begin{array}{l}-6.0803 \\
(0.0000) *\end{array}$ & $\begin{array}{l}0.0215 \\
(0.9555)\end{array}$ & $\begin{array}{l}-6.1035 \\
(0.0000) *\end{array}$ \\
\hline LPOPULATION & $\begin{array}{l}1.2402 \\
(0.9999)\end{array}$ & $\begin{array}{l}-3.7104 \\
(0.0341)^{* *}\end{array}$ & $\begin{array}{l}6.1738 \\
(1.000)\end{array}$ & $\begin{array}{l}-2.9040 \\
(0.1712)\end{array}$ \\
\hline LPGASCON & $\begin{array}{l}-1.6897 \\
(0.4292)\end{array}$ & $\begin{array}{l}-5.7387 \\
(0.0000) *\end{array}$ & $\begin{array}{l}-1.7201 \\
(0.4145)\end{array}$ & $\begin{array}{l}-5.1491 \\
(0.0001) *\end{array}$ \\
\hline LCGDGASCON & $\begin{array}{l}-1.1980 \\
(0.6459)\end{array}$ & $\begin{array}{l}-7.6878 \\
(0.0000) *\end{array}$ & $\begin{array}{l}-1.4857 \\
(0.5147)\end{array}$ & $\begin{array}{l}-12.5847 \\
(0.0000) *\end{array}$ \\
\hline LFGASCON & $\begin{array}{l}-2.2876 \\
(0.1802)\end{array}$ & $\begin{array}{l}-6.1931 \\
(0.0000)^{*}\end{array}$ & $\begin{array}{l}-2.3158 \\
(0.1715)\end{array}$ & $\begin{array}{l}-6.2270 \\
(0.0000) *\end{array}$ \\
\hline
\end{tabular}

Source: Author's Analysis; p-value is given in parenthesis, $*$ significant at $1 \% ; * *$ significant at $5 \%$

The above table shows the results of stationarity, which suggests the rejection of non-stationarity of the variables. Based on unit root test, it has been observed that the variables become stationary at first difference. 
The estimation procedure of the error correction model has performed accordingly to Engle-Grenger procedure. It is a two-step process. In the first step, ordinary least square (OLS) is used with the variables, which are non-stationary at levels but integrated of order I (1). The stationarity of the residuals of the estimated regression equation implies a cointegration among the variables in the long- run. In the second step, error correction model is applied by using the residual from the estimated equation to the short-run behavior of the dependent variables to its long-run value [1]. The result of the estimated regression equation and stationarity of residual has been shown in Table 2. The results indicate that the error term of the estimated equation is stationary and it reflects that the variables are cointegrated, i.e. there is a long-term or equilibrium relationship between them.

We have developed two competing models to estimate the natural gas demand in India. Subsequently, natural gas demand is also estimated at sector wise such as Power, Fertilizer and City Gas Distribution (CGD). In Model A, the explanatory variables contain the price, GDP, and lag value of the explained variable. Whereas Model B includes price, GDP per capita, population and lag value of the explained variable. In order to determine the best model, we emphasize on the value of adjusted R2 and AIC criteria. In addition, the selected model should satisfy multicollinearity, serial correlation, heteroscedasticity and normality of residuals.

Table 2: Results of Cointegration Regression

\begin{tabular}{|c|c|c|c|c|c|c|c|c|}
\hline \multirow{2}{*}{$\begin{array}{l}\text { Parameters } \\
\text { Estimates }\end{array}$} & \multicolumn{2}{|c|}{ National Demand } & \multicolumn{2}{|c|}{ Power Demand } & \multicolumn{2}{|c|}{ Fertilizer Demand } & \multicolumn{2}{|c|}{ CGD Demand } \\
\hline & Model A & Model B & $\begin{array}{l}\text { Model } \\
\text { A }\end{array}$ & $\begin{array}{l}\text { Model } \\
\text { B }\end{array}$ & Model A & Model B & Model A & Model B \\
\hline $\begin{array}{l}\text { LTGASCON } \\
(-1)\end{array}$ & $\begin{array}{l}0.9475 \\
(0.0000)^{*}\end{array}$ & $\begin{array}{l}0.9514 \\
(0.0000) *\end{array}$ & & & & & & \\
\hline LPRICE & $\begin{array}{l}0.0143 \\
(0.5893)\end{array}$ & $\begin{array}{l}0.0336 \\
(0.2740)\end{array}$ & $\begin{array}{l}0.0303 \\
(0.5194 \\
)\end{array}$ & $\begin{array}{l}0.0676 \\
(0.2256 \\
)\end{array}$ & $\begin{array}{l}0.0062 \\
(0.8835)\end{array}$ & $\begin{array}{l}0.0110 \\
(0.8303)\end{array}$ & $\begin{array}{l}2.8001 \\
(0.1168)\end{array}$ & $\begin{array}{l}1.7139 \\
(0.3210)\end{array}$ \\
\hline LGDP & $\begin{array}{l}0.0309 \\
(0.0061)^{*}\end{array}$ & & $\begin{array}{l}0.0311 \\
(0.0830 \\
)\end{array}$ & & $\begin{array}{l}0.0418 \\
(0.0092) *\end{array}$ & & $\begin{array}{l}-0.5071 \\
(0.2526)\end{array}$ & \\
\hline LGDPP & & $\begin{array}{l}-0.0484 \\
(0.3819)\end{array}$ & & $\begin{array}{l}-0.1170 \\
(0.2780 \\
)\end{array}$ & & $\begin{array}{l}0.0121 \\
(0.8750)\end{array}$ & & $\begin{array}{l}2.8158 \\
(0.1369)\end{array}$ \\
\hline LPOPULATION & & $\begin{array}{l}0.1338 \\
(0.0054)^{* *}\end{array}$ & & $\begin{array}{l}0.1398 \\
(0.0589 \\
)\end{array}$ & & $\begin{array}{l}0.1761 \\
(0.0120)^{* *}\end{array}$ & & $\begin{array}{l}-2.7345 \\
(0.0799)\end{array}$ \\
\hline $\begin{array}{l}\text { LPGASCON } \\
(-1)\end{array}$ & & & $\begin{array}{l}0.9344 \\
(0.0000 \\
) *\end{array}$ & $\begin{array}{l}0.9551 \\
(0.0000 \\
)^{*}\end{array}$ & & & & \\
\hline $\begin{array}{l}\text { LFGASCON } \\
(-1)\end{array}$ & & & & & $\begin{array}{l}0.9287 \\
(0.0000) \\
*\end{array}$ & $\begin{array}{l}0.9158 \\
(0.0000) *\end{array}$ & & \\
\hline $\begin{array}{l}\text { LCGDGASCON } \\
(-1)\end{array}$ & & & & & & & $\begin{array}{l}0.3409 \\
(0.2034)\end{array}$ & $\begin{array}{l}-0.0301 \\
(0.9252)\end{array}$ \\
\hline $\mathrm{H}_{\mathrm{O}}: \delta=0$ & $\begin{array}{l}-5.0763 \\
(0.0001)^{*}\end{array}$ & $\begin{array}{l}-5.3146 \\
(0.0001)^{*}\end{array}$ & $\begin{array}{l}-5.660 \\
(0.0000 \\
)^{*}\end{array}$ & $\begin{array}{l}-6.2542 \\
(0.0000 \\
*\end{array}$ & $\begin{array}{l}-6.7073 \\
(0.0000)^{*}\end{array}$ & $\begin{array}{l}-6.6150 \\
(0.0000) *\end{array}$ & $\begin{array}{l}-5.1944 \\
(0.0015)^{*}\end{array}$ & $\begin{array}{l}-4.4394 \\
(0.0041)^{*}\end{array}$ \\
\hline
\end{tabular}

Source: Author's Analysis; p-value is given in parenthesis, ${ }^{*}$ significant at $1 \%$; $* *$ significant at $5 \%$.

Table 3: Results of Error Correction Model for national natural gas demand

\begin{tabular}{|c|c|c|c|c|}
\hline \multirow[t]{3}{*}{ Parameter Estimates } & \multicolumn{4}{|c|}{ National Gas Demand } \\
\hline & \multicolumn{2}{|l|}{ Model A } & \multicolumn{2}{|l|}{ Model B } \\
\hline & $\begin{array}{l}\mathrm{DV}= \\
\mathrm{D}(\mathrm{LTGASCON})\end{array}$ & VIF & $\begin{array}{l}\text { DV= } \\
\text { D(LTGASCON) }\end{array}$ & VIF \\
\hline D(LTGASCON (-1)) & $1.0958(0.0000)$ & 3.7852 & $1.1071(0.0779)$ & 31.5964 \\
\hline D(LPRICE) & $-0.0266(0.6143)$ & 1.1350 & $-0.0148(0.7787)$ & 1.1339 \\
\hline $\mathrm{D}($ LGDP) & $-0.0782(0.6979)$ & 1.8525 & & \\
\hline D(LGDPP) & & & $-0.08581(0.6846)$ & 1.5982 \\
\hline
\end{tabular}


Natural Gas Demand Estimation for India: Error Correction Modelling

\begin{tabular}{|l|l|l|l|l|}
\hline $\mathrm{D}(\mathrm{LPOPULATION})$ & & & $-0.2541(0.9427)$ & 17.0866 \\
\hline $\mathrm{U}(-1)$ & $-0.9215(0.0014)$ & 3.1393 & $-0.9591(0.1326)$ & 16.2784 \\
\hline Ad. $\mathrm{R}^{2}$ & 0.1323 & & 0.1286 & \\
\hline AIC & -1.5293 & & -1.5049 & \\
\hline $\begin{array}{l}\text { Serial Correlation } \\
\text { Test }\left(\mathrm{H}_{0}: \rho=0\right)\end{array}$ & $1.1002(0.5769)$ & & $0.2002(0.9047)$ & \\
\hline $\begin{array}{l}\text { Heteroskedasticity Test } \\
\left(\mathrm{H}_{\mathrm{O}}: \alpha=0\right)\end{array}$ & $6.5608(0.1610)$ & & $7.1048(0.2130)$ & \\
\hline Jarque-Bera Test & $4.7847(0.0914)$ & & $8.5619(0.0138)$ & \\
\hline
\end{tabular}

Table 4: Results of Error Correction Model for estimating natural gas demand in power sector

\begin{tabular}{|c|c|c|c|c|}
\hline \multirow[t]{3}{*}{ Parameter Estimates } & \multicolumn{4}{|l|}{ Power Demand } \\
\hline & \multicolumn{2}{|l|}{ Model A } & \multicolumn{2}{|l|}{ Model B } \\
\hline & $\mathrm{DV}=\mathrm{D}($ LPGASCON $)$ & VIF & $\begin{array}{l}\mathrm{DV}= \\
\mathrm{D}(\mathrm{LPGASCON})\end{array}$ & VIF \\
\hline D(LPGASCON (-1)) & $1.0606(0.0091)$ & 7.8974 & $1.2863(0.0430)$ & 20.2948 \\
\hline D(LPRICE) & $-0.0356(0.7194)$ & 1.1320 & $-0.0069(0.9439)$ & 1.1560 \\
\hline D(LGDP) & $0.0207(0.9528)$ & 1.5826 & & \\
\hline D(LGDPP) & & & $0.0854(0.8289)$ & 1.6163 \\
\hline D(LPOPULATION) & & & $-1.8523(0.6335)$ & 5.9316 \\
\hline $\mathrm{U}(-1)$ & $-0.9286(0.0336)$ & 7.5378 & $-1.1909(0.0674)$ & 16.4675 \\
\hline Ad. $R^{2}$ & 0.0450 & & 0.0612 & \\
\hline AIC & -0.2638 & & -0.2608 & \\
\hline $\begin{array}{l}\text { Serial Correlation } \\
\text { LM Test }\left(\mathrm{H}_{0}: \rho=0\right)\end{array}$ & $6.7541(0.0802)$ & & $8.7487(0.0677)$ & \\
\hline $\begin{array}{l}\text { Heteroskedasticity } \\
\text { Test }\left(\mathrm{H}_{\mathrm{O}}: \alpha=0\right)\end{array}$ & $0.9705(0.9142)$ & & $0.6007(0.9880)$ & \\
\hline Jarque-Bera Test & $1.5981(0.4497)$ & & $4.1458(0.1258)$ & \\
\hline
\end{tabular}

For estimating total gas demand in the country, Model A is satisfying all the set criteria of model fit. Model A does not show any sign of multicollinearity, heteroscedasticity and serial correlation. In Model A, residual is normally distributed as shown by the p-value of the Jarque-Bera test in Table 3 . First lag of the dependent variable is the only statistically significant variable and reflecting a long-run impact on the national gas demand. The coefficient of the error correction term is -0.92 suggest that about $92 \%$ of the difference between long-term and short-term national gas demand is corrected annually. Both Model A and Model B are meeting the criteria of stability as shown by Cusum test in Fig 4 (a).

The results for the power sector in Table 4 also shows similar findings. Model A satisfies all the set criteria, because of the absence of multicollinearity, heteroscedasticity, and serial correlation. Moreover, the p-value of the Jarque-Bera test indicates that residual is normally distributed. The coefficient of error correction term is -0.92 suggest that about $92 \%$ of the difference between long-term and short-term gas demand from the power sector is corrected annually. Both Model A and Model B are meeting the criteria of stability as shown by Cusum test in Fig 4 (b).

For the fertilizer sector, no model was able to fill the set criteria completely as shown in Table 5 . It could be because natural gas demand from the fertilizer sector is dependent on agriculture sector performance and thus not directly linked to economic performance or GDP. Despite the absence of serial correlation and multicollinearity, the Model A fails on heteroscedasticity test, showing that variance is inconsistency over a period of time. On the other hand, Model B shows no serial correlation and heteroscedasticity but have multicollinearity. Both the models have normally distributed residual. However, both the models are stable as shown by Cusum test in Fig 4 (C).

Table 5: Results of Error Correction Model for estimating natural gas demand in the fertilizer sector

\begin{tabular}{|c|c|c|c|c|}
\hline \multirow[t]{3}{*}{ Parameter Estimates } & \multicolumn{4}{|l|}{ Fertilizer Demand } \\
\hline & \multicolumn{2}{|l|}{ Model A } & \multicolumn{2}{|l|}{ Model B } \\
\hline & $\mathrm{DV}=\mathrm{D}($ LFGASCON $)$ & VIF & $\mathrm{DV}=\mathrm{D}($ LFGASCON $)$ & VIF \\
\hline $\mathrm{D}($ LFGASCON $(-1))$ & $1.1912(0.0002)$ & 5.4169 & $1.1048(0.0432)$ & 17.2404 \\
\hline D(LPRICE) & $-0.0621(0.4604)$ & 1.1500 & $-0.0564(0.5079)$ & 1.1495 \\
\hline $\mathrm{D}$ (LGDP) & $-0.1757(0.5744)$ & 1.7833 & & \\
\hline
\end{tabular}


International Journal of Engineering and Advanced Technology (IJEAT) ISSN: 2249-8958, Volume-8, Issue-5S3, July 2019

\begin{tabular}{|l|l|l|l|l|}
\hline $\mathrm{D}($ LGDPP) & & & $-0.2294(0.4964)$ & 1.5912 \\
\hline $\mathrm{D}($ LPOPULATION) & & & $0.5410(0.8685)$ & 5.7187 \\
\hline $\mathrm{U}(-1)$ & $-1.2898(0.0004)$ & 4.7547 & $-1.2046(0.0341)$ & 12.4553 \\
\hline Ad. $\mathrm{R}^{2}$ & 0.1070 & & 0.0834 & \\
\hline AIC & -0.6141 & & -0.5679 & \\
\hline $\begin{array}{l}\text { Serial Correlation } \\
\text { LM Test }\left(\mathrm{H}_{0}: \rho=0\right)\end{array}$ & $3.9251(0.1405)$ & $3.9038(0.1420)$ & \\
\hline $\begin{array}{l}\text { Heteroskedasticity } \\
\text { Test }\left(\mathrm{H}_{\mathrm{O}}: \mathrm{\alpha}=0\right)\end{array}$ & $11.0792(0.0257)$ & & $9.9450(0.0768)$ & \\
\hline Jarque-Bera Test & $0.1483(0.9285)$ & & $0.1945(0.9073)$ & \\
\hline
\end{tabular}

Table 6: Results of Error Correction Model for estimating natural gas demand in CGD sector

\begin{tabular}{|c|c|c|c|c|}
\hline \multirow[t]{3}{*}{ Parameter Estimates } & \multicolumn{4}{|l|}{ CGD Demand } \\
\hline & \multicolumn{2}{|l|}{ Model A } & \multicolumn{2}{|l|}{ Model B } \\
\hline & $\begin{array}{l}\mathrm{DV}= \\
\mathrm{D}(\text { LCGDGASCON })\end{array}$ & VIF & $\begin{array}{l}\mathrm{DV}= \\
\mathrm{D}(\mathrm{LCGDGASCON})\end{array}$ & VIF \\
\hline $\begin{array}{l}\text { D(LCGDGASCON } \\
(-1))\end{array}$ & $0.2637(0.5531)$ & 4.3942 & $-0.1450(0.6167)$ & 2.5756 \\
\hline D(LPRICE) & $2.5085(0.2430)$ & 1.6811 & $1.2981(0.4169)$ & 1.3198 \\
\hline D(LGDP) & $-2.0541(0.5514)$ & 1.7295 & & \\
\hline D(LGDPP) & & & $-7.1648(0.1667)$ & 4.0942 \\
\hline D(LPOPULATION) & & & $71.1713(0.0915)$ & 3.7688 \\
\hline $\mathrm{U}(-1)$ & $-1.1926(0.0407)$ & 3.8600 & $-0.6866(0.1425)$ & 2.9833 \\
\hline Ad. $R^{2}$ & 0.3729 & & 0.5460 & \\
\hline AIC & 3.5430 & & 3.2580 & \\
\hline $\begin{array}{l}\text { Serial Correlation LM } \\
\text { Test }\left(\mathrm{H}_{0}: \rho=0\right)\end{array}$ & $1.5324(0.4648)$ & & $1.7245(0.4222)$ & \\
\hline $\begin{array}{l}\text { Heteroskedasticity Test } \\
\left(\mathrm{H}_{\mathrm{O}}: \alpha=0\right)\end{array}$ & $2.9399(0.5679)$ & & $4.2265(0.5173)$ & \\
\hline Jarque-Bera Test & $0.7056(0.7027)$ & & $0.5713(0.7514)$ & \\
\hline
\end{tabular}

In CGD, the results of both the models in Table 6 show the absence of multicollinearity, serial correlation, and heteroscedasticity. Moreover, the p-value of the Jarque-Bera test indicates that residual is normally distributed in both the models. However, we have to choose Model A as the result of Cusum test in Fig 4 (d) shows that Model B is unstable. Figure 4: Model Stability

a) National Demand Model 1

Model 2
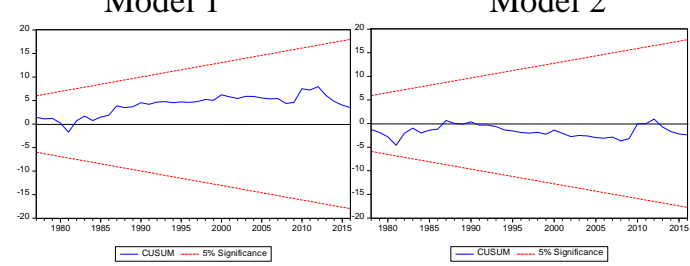

b) Power Demand

Model 1

Model 2

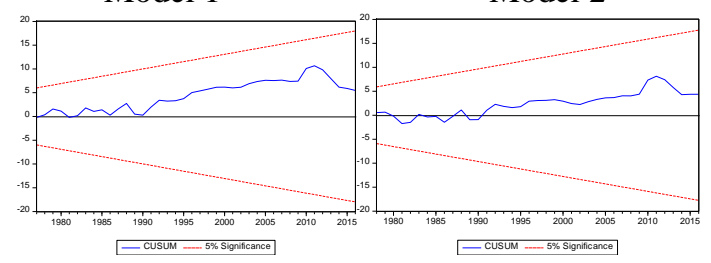

c) Fertilizer Demand

Model 1

Model 2

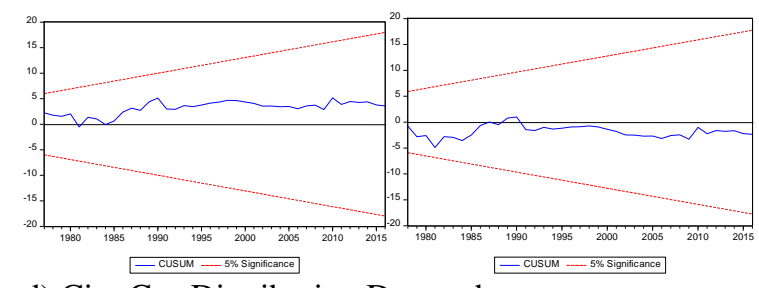

d) City Gas Distribution Demand Model 1

Model 2

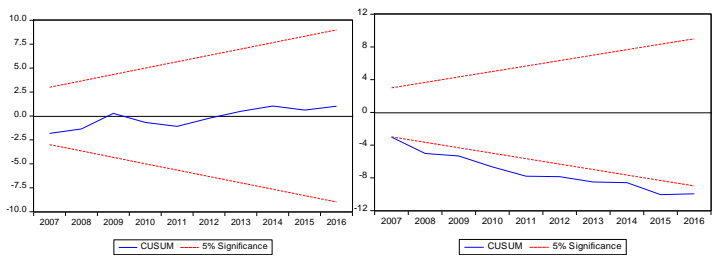

V. Conclusion And Policy ImPlications

Since the variables are in logarithms, the estimated parameters represent elasticities in both short-run and long-run. As per the economic theory, normal good demand has a negative correlation with price. In the opted for national natural gas demand (Model A) in long-run is showing the price inelasticity of demand, which is inconsistent according to the existing theory of economics. On the contrary, the price elasticity of demand is negative in short-run. 
However, in both conditions, the estimated value of the coefficient is statistically insignificant. This may happen because of the low price of natural gas in the country, which is making consumer insensitive towards price change. The income elasticity of gas demand is inelastic with a positive sign and statistically significant in long-run. Last year gas consumption is the only value, which is statistically significant in short and long-run. In the short run, it is more effective because of high elasticity.

In the power sector, gas demand is inelastic to income and prices in long-run under Model A. It could be true in the case of India as the power sector is highly subsidized and dominated by coal. Whereas in short-run, demand is elastic to last year consumption. In fertilizer, income is statistically significant but inelastic to demand in long-run. In short-run, the last year consumption elasticity measured for fertilizer is $119 \%$. For the CGD sector, we could not find any model specification that fits the data. It is not abnormal, as this sector is in the early stages of development in the country. Although many licensing rounds have taken place for CGD network development, natural gas demand generation will take because of the long gestation period and slow population coverage.

In order to ensure sustainable economic growth, India needs to ensure the consistent supply of energy. We believe natural gas can play a crucial in meeting the growing energy demand in India. It could be the clean fuel to replace coal in the long term. However, it would require long-term planning and estimate natural gas demand. We used a dynamic econometric model to dynamics of natural gas demand in India, both in the national and sectoral level. Our model throws interesting insights, which can be used by the policymakers in achieving the goal of having $15 \%$ share of natural gas in the energy mix by 2022. We found that income, price, and population are statistically insignificant in the natural gas estimation, indicating that there might be a suppressed demand within the country. The government focus on the continuous expansion of CGD network expansion could provide the necessary thrust to the natural gas industry as it serves end consumers on a wider scale. The expansion of pipeline infrastructure is imperative for the growth of CGD network, as it will enable LPG consumer to switch to PNG and establish CNG as the preferred fuel for transportation.

\section{REFERENCES}

[1] J. a. P. BODGER, "Further Issues in Forecasting Primary Energy Consumption," TECHNOLOGICAL FORECASTING AND SOCIAL CHANGE, pp. 267-280, 1984.

[2] G. R. Subhes C.Bhattacharyyaa, "Modelling energy demand of developing countries: Are the specific features adequately captured?," Energy Policy, pp. 1979-1990, April 2010.

[3] S. I. S. Jebaraja, "A review of energy models," Renewable and Sustainable Energy Reviews, pp. 281-311, 2006.

[4] R. B. H. M. F. Urban, "Modelling energy systems for developing countries," Energy Policy, p. 3473-3482, 2007.

[5] "Shell World Energy Model," Shell International, Amsterdam, 2017.

[6] E. Erdogdu, "Natural gas demand in Turkey," Applied Energy, pp. 211-219, 2010.

[7] X. D. J. S. M. H. Junchen Li, "Forecasting the growth of China's natural gas consumption," Energy, pp. 1380-85, 2011.

[8] A. Wright, "8 things you need to know about India's economy," 1 October 2017. [Online]. Available: https://www.weforum.org/agenda/2017/10/eight-key-facts-about-indias -economy-in-2017/.
[9] W. Bank, "Data Bank," World Bank, 1226 2018. [Online]. Available: https://databank.worldbank.org/data/home.aspx. [Accessed 252 2019].

[10] A. Wright, "8 things you need to know about India's economy," 1 October 2017. [Online]. Available: https://www.weforum.org/agenda/2017/10/eight-key-facts-about-indias -economy-in-2017/. [Accessed 21 2019].

[11] BP, "Statistical Review of World Energy," BP, London, 2018.

[12] PPAC, "Petroleum Planning \& Analysis Cell," 3112 2018. [Online]. Available:

https://www.ppac.gov.in/content/153_1_ImportNAturalgas.aspx. [Accessed 801 2019].

[13] S. Cornot-Gandolphe, "India's vision to a gas-based economy Drivers and Challenges," CEDIGAZ, 10 October 2017. [Online]. Available: https://www.cedigaz.org/indias-vision-gas-based-economy-drivers-chal lenges/. [Accessed 0801 2019].

[14] P. Bodger and J. T. Baines, "Further Issues in Forecasting Primary Energy Consumption," TECHNOLOGICAL FORECASTING AND SOCIAL CHANGE, vol. 26, no. 3, pp. 267-280, 1984.

[15] S. C. Bhattacharyya and G. R. Timilsina, "Modelling energy demand of developing countries: Are the specific features adequately captured?," Energy Policy, vol. 38, no. 4, pp. 1979-1990, April 2010.

[16] S. Jebaraj and S. Iniyan, "A review of energy models," vol. 10, no. 4, pp. 281-311, August 2006.

[17] F. Urban, H. C. Mall and R. M. Benders, "Modelling energy systems for developing countries," Energy policy, vol. 35, no. 6, pp. 3473-3482, June 2007.

[18] Thomas, Wim; Haigh, Martin, "World Energy Model A View To 2010," Shell International BV, The Hague, 2017.

[19] E. Erdogdu, "Natural Gas Demand In Turkey," Applied Energy, vol 87 , no. 1, pp. 211-219, 2010.

[20] L. Junchen, D. Xiucheng, S. Jianxin and M. Hook, "Forecasting the growth of China's natural gas consumption," Energy, vol. 36, no. 3, pp. 1380-1385, March 2011.

[21] S. K. Mukherjee, "Energy policy and planning in India," Energy, vol. 6 , no. 8, pp. 823-851, 1981.

[22] R. D. Rao and J. K. Parikh, "Forecast and analysis of demand for petroleum products in India," Energy Policy, vol. 24, no. 6, pp. 583-592, June 1996.

[23] B. S. Reddy and P. Balachandra, "Integrated energy-environment-policy analysis — a case study of India," Utilities Policy, vol. 11, no. 2, pp. 59-73, 2003.

[24] J. Parikh, P. Purohit and P. Maitra, "Demand projections of petroleum products and natural gas in India," Energy, vol. 32, no. 10, pp. 1825-1837, 2007.

[25] S. Jebaraj, S. Iniyan and H. Kota, "Forecasting of commercial energy consumption in India using Artificial Neural Network," International Journal of Global Energy Issues, vol. 27, no. 3, pp. 276-301, 2007.

[26] C. K. R. S. D. Cleveland, "Aggregation and the role of energy in the economy," Ecological Economics, vol. 32, no. 2, pp. 301-317, 2000.

[27] R. W. B. Ayres, "Accounting for growth: the role of physical work," Structural Change and Economic Dynamics, vol. 16, no. 2, pp. 181-209, 2005

[28] Chien-ChiangLee, "Energy consumption and GDP in developing countries: A cointegrated panel analysis," Energy Economics, vol. 27, no. 3, pp. 415-427, 2005.

[29] I. M. W. Huson Joher Ali Ahmed, "Role of oil price shocks on macroeconomic activities: An SVAR approach to the Malaysian economy and monetary responses," Energy policy, vol. 39, no. 12, pp. 8062-8069, 2011.

[30] J. B. Alam, Z. Wadud and J. W. Polak, "Energy demand and economic consequences of transport policy," International Journal of Environment Science and Technology, vol. 10, no. 5, pp. 1075-1082, 2013.

[31] G. J. Daniel and S. Glaister, "The Demand for Automobile Fuel: A Survey of Elasticities," Journal of Transport Economics and Policy, vol. 36 , no. 1, pp. 1-25, 2002.

[32] D. Gately and H. Huntington, "The Asymmetric Effects of Changes in Price and Income on Energy and Oil Demand," The Energy Journal, vol 23, no. 1, pp. 19-55, 2002.

[33] P. I. Bureau, "Revision of Domestic Gas Prices," Government of India, New Delhi, 2014.

[34] M. o. S. a. P. Implementation, "Energy Statistics," Government of India, New Delhi, 2018. 
[35] RBI, "Handbook of Statistics on Indian States," Reserve Bank of India, $15 \quad 3 \quad 2018 . \quad$ [Online]. Available: https://rbi.org.in/Scripts/AnnualPublications.aspx?head=Handbook\%2 0of\%20Statistics\%20on\%20Indian\%20States. [Accessed 1512019 ].

[36] R. F. Engle and C. W. Granger, "Co-Integration and Error Correction: Representation, Estimation, and Testing," Econometrica, vol. 55, no. 2, pp. 251-276, 1987.

\section{Authors ProfiLe}

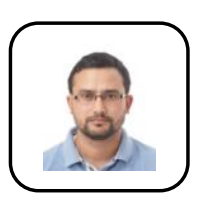

Atul Rawat, is working as an Assistant Professor, with Department of Enegry Management in School of Business, University of Petroleum \& Energy Studies. He has more than twelve years of experience in energy research and consulting domain. His area of specialization are petroleum fiscal regimes, oil and gas markets..

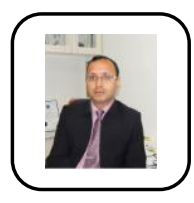

Dr. Sumeet Gupta, Senior Associate Professor (Finance), Department of General Management has more than 19 Years of academic experience. He has published several research papers and case studies in renowned journals. He is a certified Public Forensic Accountants from Institute of Forensic Accountants , USA.

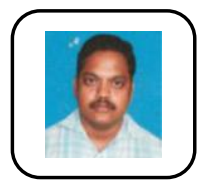

Dr. T. Joji Rao, Senior Associate Professor (Finance), Department of General Management. He did his Ph.D from Samalpur University and has more than 18 years of academic and industry experience. His area of

specialization are oil and gas accounting, risk management and insurance.

Dr. S. K. Rai, Sushil Kumar Rai has a Ph.D. in Economics from the Banaras Hindu University (BHU), Varanasi. Presently, he is working at School of Business (SOB), University of Petroleum and Energy Studies, Dehradun where he teaches in Master's degree and undergraduate courses. He is also supervising researches in the area of macroeconomics. His research interests are in the field of development economics, international economics, small and medium enterprises and energy economics 